\title{
Front Matter: Volume 8547
}

, "Front Matter: Volume 8547," Proc. SPIE 8547, High-Power Lasers 2012: Technology and Systems, 854701 (8 November 2012); doi: 10.1117/12.2014714

SPIE. Event: SPIE Security + Defence, 2012, Edinburgh, United Kingdom 


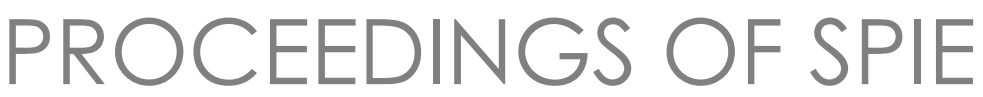

\title{
High-Power Lasers 2012: Technology and Systems
}

\author{
Harro Ackermann \\ Willy L. Bohn \\ Editors
}

24-26 September 2012

Edinburgh, United Kingdom

Sponsored by

SPIE

Cosponsored by

SELEX GALILEO • THALES

Delivered with the support of

Scottish Development International • Scottish Enterprise

Cooperating Organisations

DSTL (United Kingdom) • IOP Instrument Science and Technology Group (United Kingdom) Scottish Optoelectronics Association (United Kingdom)

Electronics Sensors and Photonics Knowledge Transfer Network (United Kingdom)

Published by

SPIE 
The papers included in this volume were part of the technical conference cited on the cover and title page. Papers were selected and subject to review by the editors and conference program committee. Some conference presentations may not be available for publication. The papers published in these proceedings reflect the work and thoughts of the authors and are published herein as submitted. The publisher is not responsible for the validity of the information or for any outcomes resulting from reliance thereon.

Please use the following format to cite material from this book:

Author(s), "Title of Paper," in High-Power Lasers 2012: Technology and Systems, edited by Harro Ackermann, Willy L. Bohn, Proceedings of SPIE Vol. 8547 (SPIE, Bellingham, WA, 2012) Article CID Number.

ISSN: 0277-786X

ISBN: 9780819492883

Published by

SPIE

P.O. Box 10, Bellingham, Washington 98227-0010 USA

Telephone +1 3606763290 (Pacific Time) · Fax +1 3606471445

SPIE.org

Copyright (C) 2012, Society of Photo-Optical Instrumentation Engineers.

Copying of material in this book for internal or personal use, or for the internal or personal use of specific clients, beyond the fair use provisions granted by the U.S. Copyright Law is authorized by SPIE subject to payment of copying fees. The Transactional Reporting Service base fee for this volume is $\$ 18.00$ per article (or portion thereof), which should be paid directly to the Copyright Clearance Center (CCC), 222 Rosewood Drive, Danvers, MA 01923. Payment may also be made electronically through CCC Online at copyright.com. Other copying for republication, resale, advertising or promotion, or any form of systematic or multiple reproduction of any material in this book is prohibited except with permission in writing from the publisher. The CCC fee code is 0277-786X/12/\$18.00.

Printed in the United States of America.

Publication of record for individual papers is online in the SPIE Digital Library.

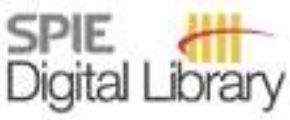

SPIEDigitalLibrary.org

Paper Numbering: Proceedings of SPIE follow an e-First publication model, with papers published first online and then in print and on CD-ROM. Papers are published as they are submitted and meet publication criteria. A unique, consistent, permanent citation identifier (CID) number is assigned to each article at the time of the first publication. Utilization of CIDs allows articles to be fully citable as soon as they are published online, and connects the same identifier to all online, print, and electronic versions of the publication. SPIE uses a six-digit CID article numbering system in which:

- The first four digits correspond to the SPIE volume number.

- The last two digits indicate publication order within the volume using a Base 36 numbering system employing both numerals and letters. These two-number sets start with $00,01,02,03,04$, $05,06,07,08,09,0 A, 0 B \ldots$. 0Z, followed by 10-1Z, 20-2Z, etc.

The CID Number appears on each page of the manuscript. The complete citation is used on the first page, and an abbreviated version on subsequent pages. Numbers in the index correspond to the last two digits of the six-digit CID Number. 


\section{Contents}

vii Conference Committee

HIGH POWER LASER SYSTEMS AND DEMONSTRATIONS

854704 Overview of the laser activities at Rheinmetall Waffe Munition (Invited Paper) [8547-3]

K. Ludewigt, Th. Riesbeck, B. Schünemann, A. Graf, M. Jung, Rheinmetall Waffe Munition

GmbH (Germany); T. Schreiber, R. Eberhardt, A. Tünnermann, Fraunhofer Institute for

Applied Optics and Precision Engineering (Germany)

854705 Recent developments and near term directions for Navy laser weapons system (LaWS) testbed (Invited Paper) [8547-4]

R. J. Pawlak, Naval Surface Warfare Ctr. Dahlgren Div. (United States)

854706 Spectrally beam combined fiber lasers for high power, efficiency, and brightness (Invited Paper) [8547-5]

R. S. Afzal, E. Honea, M. Savage-Leuchs, N. Gitkind, R. Humphreys, J. Henrie, K. Brar,

D. Jander, Lockheed Martin Aculight (United States)

854708 High-power beam combining: a step to a future laser weapon system (Invited Paper)

[8547-7]

R. Protz, J. Zoz, F. Geidek, S. Dietrich, M. Fall, MBDA Germany (Germany)

\section{GAS LASER TECHNOLOGY I}

854709 Diode-pumped alkali laser-bleached wave dynamics (Invited Paper) [8547-8]

G. P. Perram, W. Miller, E. Hurd, Air Force Institute of Technology (United States)

8547 OA Determination of low pressure broadening and shift rates for Cs collisions with rare gases from Anderson Tallman theory [8547-9]

G. D. Hager, M. D. Rotondaro, G. P. Perram, Air Force Institute of Technology

(United States)

THIN DISK LASER TECHNOLOGY

8547 OB High-power thin disk lasers (Invited Paper) [8547-10]

A. Giesen, J. Speiser, Deutsches Zentrum für Luft- und Raumfahrt e.V. (Germany)

8547 OC Recent disk laser development at Trumpf (Invited Paper) [8547-1 1]

T. Gottwald, C. Stolzenburg, D. Baver, J. Kleinbauer, V. Kuhn, TRUMPF Laser GmbH and Co.

KG (Germany); T. Metzger, TRUMPF Laser GmbH and Co. KG (Germany)

S.-S. Schad, D. Sutter, A. Killi, TRUMPF Scientific Lasers GmbH and Co. KG (Germany) 
8547 OD High energy high brightness thin disk laser (Invited Paper) [8547-12]

M. D. Nixon, M. C. Cates, Boeing Directed Energy Systems (United States)

$8547 \mathrm{OE}$ Thin disk laser in the $\mathbf{2} \boldsymbol{\mu m}$ wavelength range [8547-13]

J. Speiser, G. Renz, A. Giesen, Deutsches Zentrum für Luft- und Raumfahrt e.V. (Germany)

\section{ULTRASHORT PULSE LASERS AND APPLICATIONS}

8547 OG Triggering and guiding electric discharge by a train of ultrashort UV pulses and a long UV pulse emitted by a hybrid Ti:Sapphire-KrF laser facility (Invited Paper) [8547-15]

A. A. Ionin, S. I. Kudryashov, A. O. Levchenko, L. V. Seleznev, A. V. Shutov, D. V. Sinitsyn, I. V. Smetanin, N. N. Ustinovskiy, V. D. Zvorykin, P.N. Lebedev Physical Institute (Russian Federation)

$8547 \mathrm{OH}$ Experimental component of the AFOSR-supported MURI program on ultrafast laser filamentation in transparent dielectric media (Invited Paper) [8547-16]

P. G. Polynkin, College of Optical Sciences, The Univ. of Arizona (United States)

8547 Ol Power scaling of high-power optically pumped semiconductor lasers for continuous wave and ultrashort pulse generation [8547-17]

A. Laurain, College of Optical Sciences, The Univ. of Arizona (United States); M. Scheller, College of Optical Sciences, The Univ. of Arizona (United States) and Nonlinear Control Strategies Inc. (United Kingdom); T.-L. Wang, College of Optical Sciences, The Univ. of Arizona (United States); J. Hader, J. V. Moloney, College of Optical Sciences, The Univ. of Arizona (United States) and Nonlinear Control Strategies, Inc. (United States); S. W. Koch, College of Optical Sciences, The Univ. of Arizona (United States) and Nonlinear Control Strategies, Inc. (United States), Philipps-Univ. Marburg (Germany); B. Heinen, M. Koch, Philipps-Univ. Marburg (Germany); B. Kunert, W. Stolz, Philipps-Univ. Marburg (Germany) and NAsP III/V GmbH (Germany)

\section{FIBER LASER TECHNOLOGY}

8547 0J All-solid photonic bandgap fibers for high power lasers (Invited Paper) [8547-18]

L. Dong, Clemson Univ. (United States); K. Saitoh, Hokkaido Univ. (Japan); F. Kong, P. Foy, T. Hawkins, D. Mcclane, G. Gu, Clemson Univ. (United States)

8547 OK Single crystal fibers for high power lasers (Invited Paper) [8547-19]

W. Kim, U.S. Naval Research Lab. (United States); C. Florea, Sotera Defense Solutions, Inc. (United States); C. Baker, D. Gibson, L. B. Shaw, S. Bowman, S. O'Connor, G. Villalobos, S. Bayya, U.S. Naval Research Lab. (United States); I. D. Aggarwal, Sotera Defense Solutions, Inc. (United States); J. S. Sanghera, U.S. Naval Research Lab. (United States);

\section{BEAM COMBINING TECHNOLOGY}

$854700 \quad$ New design for passive coherent coupling of fiber lasers (Invited Paper) [8547-23] F. JeuX, XLIM Institut de Recherche, CNRS, Univ. de Limoges (France) and Astrium SAS (France); A. Desfarges-Berthelemot, V. Kermène, A. Barthelemy, XLIM Institut de Recherche, CNRS, Univ. de Limoges (France); D. Sabourdy, J.-E. Montagne, CILAS (France) 
8547 OP Monolithic eye-safer photonic crystal fiber lasers and amplifiers (Invited Paper) [8547-24]

C. G. Carlson, B. G. Ward, U.S. Air Force Academy (United States); D. L. Sipes Jr.,

J. D. Tafoya, Optical Engines, Inc. (United States)

8547 OR Beam combining concepts using Stimulated Brillouin Scattering [8547-26]

A. M. Scott, QinetiQ Ltd. (United Kingdom)

\section{SOLID STATE AND SEMICONDUCTOR LASER TECHNOLOGY}

8547 OU Coherent polarization locking of thermal-sensitive Ho:YAG laser [8547-29]

C. F. Chua, L. H. Tan, P. B. Phua, Nanyang Technological Univ. (Singapore)

8547 OV Recent advances in eye-safe Er:YAG solid-state heat-capacity technology (Invited Paper) [8547-30]

M. Eichhorn, S. Bigotta, T. Ibach, Institut Franco-Allemand de Recherches de Saint-Louis (France)

8547 OW Transient analysis of thermal effects in non-symmetrically pumped laser slabs [8547-31]

E. Spinozzi, M. Vitiello, GEM Elettronica srl (Italy)

8547 0X Overview on new diode lasers for defense applications [8547-32]

J. Neukum, DILAS Diodenlaser GmbH (Germany)

\section{GAS LASER TECHNOLOGY II}

$8547 \mathrm{OZ}$ Gain and lasing of optically pumped metastable rare gas atoms (Invited Paper) [8547-34]

J. Han, M. C. Heaven, Emory Univ. (United States)

854710 Modeling of static and flowing-gas diode pumped alkali lasers [8547-35]

B. D. Barmashenko, S. Rosenwaks, Ben-Gurion Univ. of the Negev (Israel)

$854711 \quad$ Advanced CO laser systems [8547-36]

A. Ionin, P.N. Lebedev Physical Institute (Russian Federation)

POSTER SESSION

854712 Analysis of a passively q-switched Nd:YAG slab laser oscillator/amplifier system [8547-37] I. I. Lancranjan, Advanced Study Ctr.-INCAS (Romania); D. Savastru, S. Miclos, R. Savastru, National Institute of Research and Development for Optoelectronics (Romania)

Author Index 
Proc. of SPIE Vol. $8547854701-6$

Downloaded From: https://www.spiedigitallibrary.org/conference-proceedings-of-spie on 26 Apr 2023 Terms of Use: https://www.spiedigitallibrary.org/terms-of-use 


\title{
Conference Committee
}

\author{
Symposium Chairs \\ David H. Titterton, Defence Science and Technology Laboratory \\ (United Kingdom) \\ Reinhard R. Ebert, Fraunhofer-Institut für Optronik, Systemtechnik und \\ Bildauswertung (Germany) \\ Conference Chairs
}

Harro Ackermann, High Energy Laser Joint Technology Office (United States)

Willy L. Bohn, BohnLaser Consult (Germany)

Session Chairs

1 High Power Laser Systems and Demonstrations I

Harro Ackermann, High Energy Laser Joint Technology Office (United States)

Willy L. Bohn, BohnLaser Consult (Germany)

2 High Power Laser Systems and Demonstrations II

Harro Ackermann, High Energy Laser Joint Technology Office (United States)

Willy L. Bohn, BohnLaser Consult (Germany)

3 Gas Laser Technology I

Glen P. Perram, Air Force Institute of Technology (United States)

$4 \quad$ Thin Disk Laser Technology

Adolf Giesen, Deutsches Zentrum für Luft- und Raumfahrt e.V. (Germany)

5 Ultrashort Pulse Lasers and Applications

Czeslaw Radzewicz, University of Warsaw (Poland)

6 Fiber Laser Technology

Jens Limpert, Friedrich-Schiller-Universität Jena (Germany)

7 Beam Combining Technology

Jens Limpert, Friedrich-Schiller-Universität Jena (Germany) 
8 Solid State and Semiconductor Laser Technology Mark Dubinskii, U.S. Army Research Laboratory (United States)

9 Gas Laser Technology II

Glen P. Perram, Air Force Institute of Technology (United States) 